\title{
Investigation of Entrepreneurial Structures Forest Management Performance of Forestry System in Sparsely Forest-Poor Region
}

\author{
Svetlana S. Morkovina ${ }^{1}$, Irina V. Sibiryatkina ${ }^{1}$, Elena M. Konovalova ${ }^{2} \&$ Daniil S. Bourtsev $^{3}$ \\ ${ }^{1}$ Voronezh State Academy of Forestry and Technologies, Voronezh, Russia \\ ${ }^{2}$ Voronezh branch of Plekhanov Russian University of economics, Voronezh, Russia \\ ${ }^{3}$ St.Petersburg Forestry Research Institute, St. Petersburg, Russia \\ Correspondence: Svetlana S. Morkovina, Voronezh State Academy of Forestry and Technologies, Timiryazeva \\ st., 8, Voronezh, 394613, Russia. Tel: 7-0732-53-74-98. E-mail: postmaster@julygb.vsi.ru
}

Received: August 20, 2014 Accepted: September 12, 2014 Online Published: November 14, 2014

doi:10.5539/ass.v10n23p20 URL: http://dx.doi.org/10.5539/ass.v10n23p20

\begin{abstract}
The article presents the results of analysis of the performance and use of forests entrepreneurial structures forestry sparsely wooded region of Russia. Based on the results of Jas-survey of managers of businesses - forest users are disclosed factors that determine the attractiveness of the business activities in the field of forestry species composition and age of the forest stand, and forest conditions that do not depend on the quality of economic activity of enterprise structure. It has been established that the economic accessibility of forest resources is not always significantly reflects the entrepreneurial interest in a forest, which necessitates more accurate method for determining the entrepreneurial income. Consideration methodical approach to reviewing the effectiveness of the functioning and organization of forest management enterprise structures in forestry and sparsely wooded region are two models of business organization in the forestry sector in the forest-poor region.
\end{abstract}

Keywords: forest, forest-poor region, the method of analysis, effectiveness, entrepreneurial income

\section{Introduction}

The problem of sustainable economic growth in a country is associated with increased development management of its sectors (Popkova et al., 2013). Forest sector brings together forestry timber and lumber industries. Known, the performance the industry are income from worker-ness, in the forestry sector to the last rank as well as forest revenues received by state as the owner of Woodland for the use of forest resources in the form of charged to tenants woodlots payments (in the recent past as a part of total income of forestry were up to 50\%) (Tchaikovsky, 2007). Lightly used in environmental management and, particularly, to ensure effective forest management, the regulatory function of the state has made previously profitable forest industry in unprofitable (Zozulya, 2010).

Income of entrepreneurial activity in the forestry sector is sales of timber products, services. It is important to note that the evaluation of entrepreneurial income is necessary to consider the fact that the lease forest areas suggests the possibility of implementing multi-purpose functions of forest resources - the latter can be used for different purposes at the same time (hunting, harvesting mushrooms, harvesting, growing seedlings in forest nurseries) or only one of them (Bao, 2013). In recent years, the loss ratio of the forest sector of Russia's economy is growing, which actualizes the issues related to ensuring effectiveness of business organizations in the forestry sector and cost optimization in the timber (Popkova et al., 2013).

It is characteristic that the forest is significantly different from other types of entrepreneurial activities of a state monopoly on the forest; high role in ensuring the income of natural and plant conditions; the need for reproduction of resources; multivariance use of wood with different economic effect; presence of a large number of small enterprises in forestry; necessarily Stu compliance with environmental law, et al. (Petrov, 2012) In this communication con-how to predict and guarantee the result of entrepreneurial activity in the timber is problematic because business organizations are faced with a certain amount of risk factors that greater or lesser extent incalculable and complicate business in general. Agreeing with the opinion of P. Drucker, who believes that the impact is due to the fact that "made the necessary and the right thing" and is the result of certain processes, carry out the functions, tasks, achieve goals (Drucker, 1992), we note the specificity of Forestry. How different economic interests of the forest relations - States and users, so the problem faced by entrepreneurs in 
forestry often contradictory is to maximize profits from logging and reforestation quality suggesting considerable entrepreneurial costs. Distinctive features of entrepreneurial activity in the forestry sector, outlined above, determine the need for clarification of the process of formation of separate categories - income and expenses from the forest.

Then the question arises about the formation of the methods of analysis effectively organization of forest management, the use of which in the practice of business structures allow reasonably come to the conclusion of the lease agreement for the use of forest lands in order to meet forest management and the inevitability of business costs of reforestation.

\section{Method}

To investigate the effectiveness of business activities in the field of forestry in the forest-poor region at the Voronezh region of the Central region of Russia were surveyed small and medium enterprises in carrying out forest leases a total of 494 for the type of use of forests (Table 1)

Table 1. Characteristics and use of forests in 2013

\begin{tabular}{ccc}
\hline Type of forests & Number of leases & Leased area, ha \\
\hline - Timber harvesting; & 13 & 163716.1 \\
- Activities in the field of hunting; & 7 & 13387.00 \\
- Farming & 145 & 95.54 \\
- Implementation of recreational activities; & 329 & 627.64 \\
all & 494 & 177826.28 \\
\hline
\end{tabular}

Providing forest leases sparsely region was carried out in accordance with the Forest Code of the Russian Federation, signed a lease agreement for after-blowing uses of forests:

- blank $92 \%$ of the total number of leased forest lands;

- implementation of activities in the field of hunting - $6 \%$;

- agriculture - $1.5 \%$;

- implementation of recreational activities - $0.5 \%$, and others.

For the formation of the unit yield, data of authorities of subjects of the Russian Federation (sparsely regions) in the area of forest relations.

At the first stage in the context of forestry were identified forest area, used by tenants under the various types of forests; defined area and set the amount of forest management contracts for the sale of forest plantations under government contracts (concluded with placing an order for the execution of works for protection, conservation, reforestation), as well as purchase and sale agreements, signed on the results of auctions.

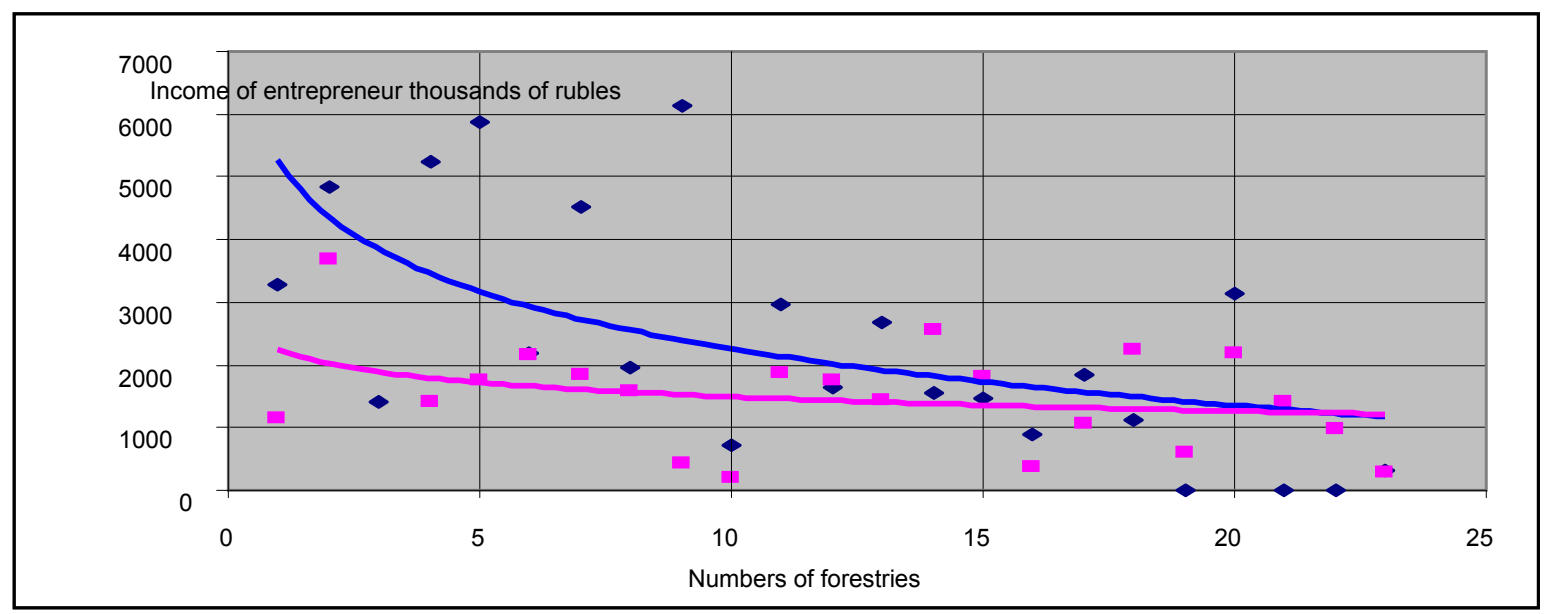

Figure 1. Entrepreneurial income in forest management: timber (blue marker), recreation (red marker)

With respect to forest lands leased under logging and cover the entire area of forest, the yield per unit area was calculated as the ratio of the rent accrued for the year to the area of the leased area. 
By a survey of business leaders working in the field of forestry were established maximum and minimum income business structures by type and use of forests in the dynamics of the three years. For the treatment of information obtained there was used the method by summarizing reports and group data. Average business income for 2008-2013, determined with certainty 0.997 , while the calculated coefficient of variation was $13 \%$ (Figure 1).

As a result, calculated the average yield per unit area of forest area for different types of use by dividing the average business income on the area leased area (Table 2).

Table 2. Average entrepreneurial income per unit area of forest area, rub.

\begin{tabular}{ccccc}
\hline Year & Logging activity & Recreational activity & Agriculture & Hunting management and the hunting \\
\hline 2011 & 3487 & 14942 & 52.3 & 92.7 \\
2012 & 2832 & 38564 & 59.8 & 85.4 \\
2013 & 1593 & 61091 & 68.4 & 81.1 \\
\hline
\end{tabular}

Business income is defined as:

$$
\mathrm{D}=\sum \mathrm{V}_{\mathrm{i}} * \mathrm{Z}_{\mathrm{i}}
$$

where $V_{i}$ is volume harvested i-type of timber, or the area of forest management;

$Z_{\mathrm{i}}$ is average entrepreneurial income from forestry, $\mathrm{p}$.

On the example of 23 forest-poor regions (Voronezh region) were defined us-performance characteristics of entrepreneurial activity by type of forestry.

\section{Results}

Understanding the development of entrepreneurship in the forestry sector as a system of activities related to the investment in the forest fund of labor and capital, it is important to take into account its contribution to the economy of the forest sector and the impact of both the forest users, and for the state budget.

The importance of this approach is evidenced by the fact that during the period from 2008 to 2013, the number of tenants forest areas has increased by more than 1.5 times, while the fee for forest grew to more than 3 times. It is important to note that the fee for the use of forest resources is the basis of the state forest revenues and is part of fixed business costs. The most attractive views of forest remain timber (Table 3).

Table 3. Growth rates of indicators of entrepreneurial activity in the forest ho-farms of Voronezh region

\begin{tabular}{cccccc}
\hline indicators & \multicolumn{4}{c}{ Growth rate, $\%$ per year } \\
\cline { 2 - 6 } & 2008 & 2009 & 2010 & 2011 & 2012 \\
\hline Number of tenants & 100 & 129 & 126 & 106 & 101 \\
Fee for forestry & 100 & 154 & 152 & 246 & 104 \\
Area of leased land for logging & 100 & 113 & 110 & 159 & 163 \\
The fee for the use of forest lands for 1 ha of rented space & 100 & 89 & 156 & 171 & 102 \\
\hline
\end{tabular}

It is clear that for the development of entrepreneurship in forestry poor-forest zone must be comprehensive utilization of forest resources, and done-set in forest areas is not one but several forest management, that will not only improve the entrepreneurial income, but also reduce the cost, in terms of conditional constant.

The essence of the effectiveness of business activities in the forestry sector is reduced to the comparison of the economic results of production or you-complement individual activities with the costs they have caused (Morkovina, Zinoviev, \& Bao, 2014). Then, in considering performance of forestry in a sparsely wooded area must take into account the factors determining the formation of the revenue and cost sides of entrepreneurship.

It is important to note that in the practice of natural and organizational-economic conditions of forestry in different areas vary. There is a whole group of so-called non-regulated factors that do not depend on the quality of economic activity of enterprise structure, but connected with the peculiarities of the place of work. The group of these factors could include: the species composition of the forest stand age, site class, forestry conditions, marketability of forest stands (yield commercial timber). On the basis of that, it becomes clear that the income of 
the entrepreneur in the forestry sector is determined as the economic availability of forest resources, or lack thereof. Under the economic availability of forest resources is understood to mean a qualitative and quantitative status and geographical location with respect to existing and planned transport routes, which at the present organizational and technical level will provide the necessary level of regulatory return (Daminov and Pikalkina, 2011). It is known that the forests, as well as other natural resources are divided into three categories - available (income from harvesting exceed the costs), marginal (income may be higher or lower costs) that are not available (expenses exceed the income from the work piece). Then, for the entrepreneur, for obvious reasons, interest is available and, in some cases, limits forest resources. In this regard, it is clear that if the forest land cost is not available, it is necessary to consider alternative options for its development. However, leased forest areas do not involve division of forest resources in the above category, which implements the principle of uncertainty in obtaining business income in forestry.

Determination of the availability of resources is achieved by the comparison of the economic categories, the price of timber products and completes its cost, including forestry and transportation to the consumer.

At the same time it should be noted that the economic accessibility of forest resources is not always fairly entrepreneurial interest in a forest, meaning that even a fully accessible forest resources can be utilized entrepreneurs due to lower demand for certain types of wood:

- On a wood-fired and over, in a completely gasified regions;

- On softwood lumber, in the absence of facilities for deep of mechanical, chemical and energy processing raw wood;

- On low-quality, hardwood and softwood of small-scale, as well as waste wood harvesting. In this regard, the formation of the business-to progress can be reflected schematically as shown in Figure 2.

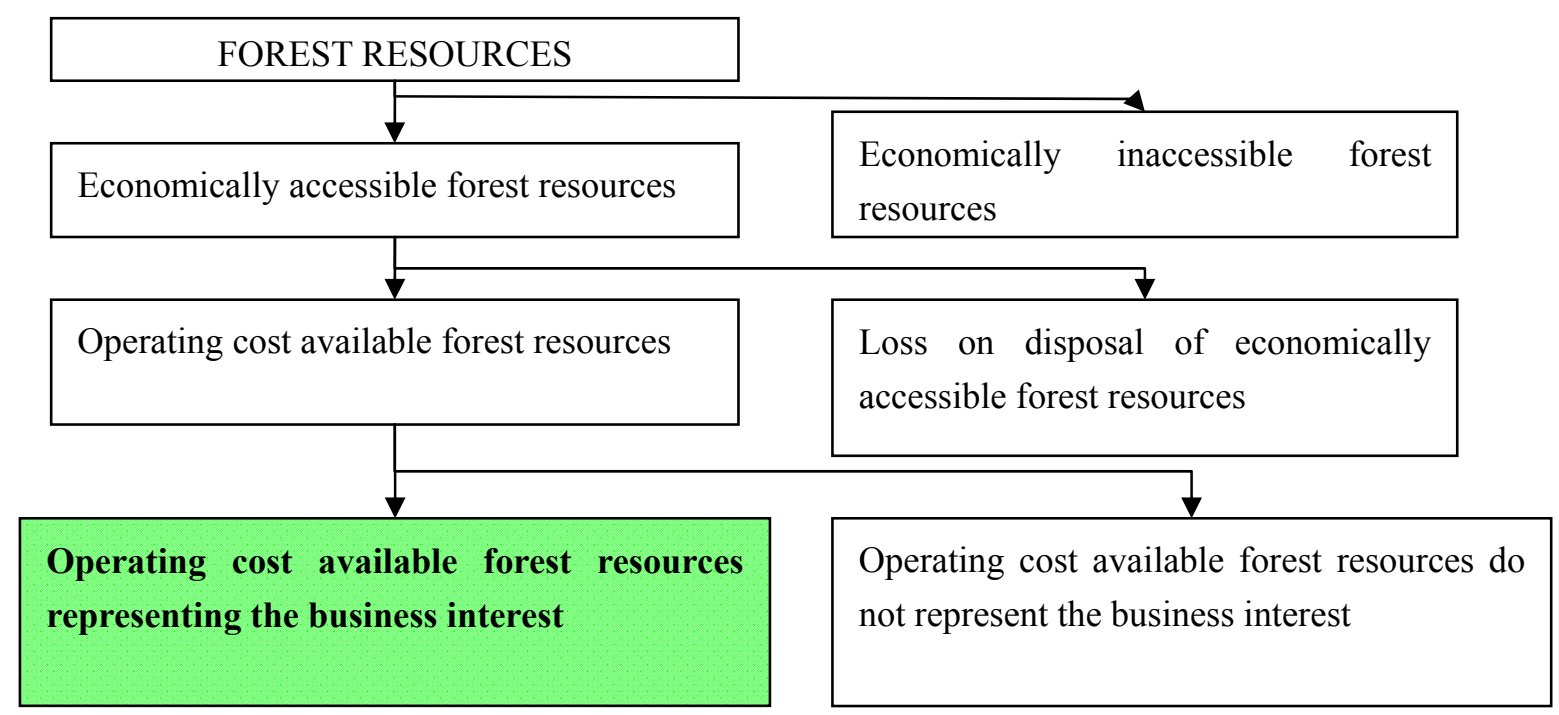

Figure 2. Formation of business income in the use of forests

Thus, we find that the income from the use of cost-access of forest resources and entrepreneurial income differ significantly.

Thus, in determining the actual business income, it is necessary to introduce a correction as to the accuracy of the accounting economically accessible forest resources and the implementation of the business interest of a forest, in the form of risk levels:

$$
\mathrm{D}=\sum \mathrm{R}_{\mathrm{i}}^{*} \mathrm{~V}_{\mathrm{i}}^{*} \mathrm{Z}_{\mathrm{i}}
$$

where $V_{i}$ is the number of $i$-species harvested for timber products or services;

$\mathrm{Z}_{\mathrm{i}}$ is price realized $\mathrm{i}$-species forest products or services;

$R_{i}$ is level of business risk shortfall $i$-species forest products or services.

Then the cost of business $(\mathrm{P})$ will be formed as: 


$$
\mathrm{P}=\mathrm{A} * \mathrm{~S}+\mathrm{Cpl}{ }^{*} \mathrm{Vpl}+\mathrm{Pd}+\mathrm{Plv}+\mathrm{H}
$$

where A is rents;

$\mathrm{S}$ is leased forest land;

$\mathrm{S}_{\mathrm{pl}}$ is rate per unit of forest resources;

$\mathrm{V}_{\mathrm{pl}}$ is Harvestable extent of forest resources;

$P_{d}$ is total direct costs of the implementation of enterprise adjustment (materials, wages, the cost of maintenance and operation of training and development of production, etc.);

$\mathrm{P}_{\mathrm{lv}}$ is cost of reforestation and forestry production;

$\mathrm{H}$ is required payments, taxes.

It is important to note that part of the cost is typical for the conduct of entrepreneurial activities, such as payment of resources, the cost of implementing enterprise-entrepreneurial activity, taxes and other payments.

Currently, the organization of work in the forestry sector is provided by the results of national or municipal orders or basis-NII contracts. The first form of the organization of work is used in forest areas, free of rent. National or municipal Zack-call can be made: the executive authorities of the Federation, a local government body, FFA, the Federal Service for Supervision in the field of nature or the federal executive body authorized in the field of defense and security. Performance of work in forestry on the basis of contracts carried out by citizens or legal persons.

Leased forest areas perform activities of forestry made by the lessee or by a third party after the conclusion of an Agreement with rent-torus. Note that the Russian Forest Code legislated for tenants forest areas forestry function: reforestation of clearings (planting forests, plantations addition, care of forest plantations, preparing the soil for nurseries, forest plantations, plantations and schools next year, and the growth material, harvesting of forest seeds, etc..), with funding these works forest users. Moreover, the costs for the implementation of forestry production on leased forest areas (logging plans by cutting the intermediate User; intermediate felling (caring for young, thinning, cuttings, renewal and reformation, selective sanitary cuttings, renovation, landscaping logging) cutting and clearing quarterly glades, cleaning litter from the forest, the construction of roads for forestry purposes, and others.) also carry renters - forest users. Thus, business organizations forestry renters forest areas are specific costs of reforestation and forestry production, which has a significant impact on the forest management and entrepreneurial income.

It is known that the result of entrepreneurial activities in forest areas defined-mined by the excess of income over expenditure, i.e. positive value of the income of the enterprise subject to the payment of all payments, the implementation of Regalement activities.

In the case where the specific trader high costs, i.e. significantly pre-back typical interest in the implementation of forest management falls. Then we should install the indicators of entrepreneurial interest in forest management, knowledge-large extent take into account the specificity of the latter. In our view such specific indicators of effectiveness of business activities in forest areas are:

- quantifying performance indicators economically accessible forest resources, representing business interests;

- exponent of the rent for the unit of forest management;

- indicators of the costs of reforestation and forest production per unit of forest management.

Moreover, in determining the maximum allowable forest management to enterprise structures, it is necessary to exclude economically unavailable resources and loss of volume in the income of the entrepreneur. This methodical approach-sky demonstrates data in Table 4.

Analyzing the data in the table, we conclude that the activities of business organizations engaged in logging in the forest area are sparsely unprofitable. The only exceptions are companies operating in forest areas with highly productive plantations - Telermanovsky boron, boron Khrenovoe.

Revenue growth will not contribute as low levels of logging and forestry operations, which do not allow to use expensive high-performance machines and mechanisms as a basis for reducing operating costs. In this case, the tenant before starting work on the forest land is necessary to have an initial capital for the purchase of fixed and current assets, allowing organize the production process. 
Table 4. Detail of the formation of entrepreneurial income from forestry (logging) in the context of individual forest areas of the Voronezh region, thousands of rubles

\begin{tabular}{cccccccc}
\hline Name of forestry & $\begin{array}{c}\text { Income } \\
\text { from } \\
\text { logging }\end{array}$ & $\begin{array}{c}\text { Risk-based } \\
\text { income }\end{array}$ & $\begin{array}{c}\text { Business } \\
\text { costs }\end{array}$ & $\begin{array}{c}\text { Fuel } \\
\text { encumbrance }\end{array}$ & $\begin{array}{c}\text { Rents } \\
\text { for } \\
\text { forest }\end{array}$ & $\begin{array}{c}\text { Total } \\
\text { expenditure }\end{array}$ & $\begin{array}{c}\text { The result of } \\
\text { entrepreneurial } \\
\text { activity }\end{array}$ \\
\hline Ostrogozhskoe & 23115 & 19647 & 19200 & 269 & 59345 & 78814 & -59167 \\
Telermanovskoe & 47955 & 40761 & 26332 & 558 & 19151 & 46041 & -5280 \\
Kalacheevskogo & 11500 & 9775 & 32654 & 134 & 16753 & 16887 & -7112 \\
Buturlinovskoe & 34730 & 29520 & 29634 & 404 & 95218 & 125256 & -95736 \\
Pavlovianoe & 14145 & 12023 & 6619 & 164 & 17282 & 24065 & -12042 \\
Bobrovskoye & 34500 & 29325 & 11263 & 402 & 14569 & 26234 & 3091 \\
Vorontsovskoye & 33350 & 28347 & 18415 & 388 & 175632 & 194435 & -166088 \\
Anninskoe & 21620 & 18377 & 22514 & 251 & 79372 & 79623 & -61246 \\
Voronezhskoe & 31050 & 26392 & 21111 & 361 & 11644 & 33116 & -6724 \\
\hline
\end{tabular}

It is known that one of the factors that influence the development of forestry is forestland transport development. Increasing the density of the road network in the forest fund is beneficial to the development of entrepreneurship, what proof - effective functioning of business organizations in the forests surrounding the major cities. Given the fact that timber harvesting and recreational activities are the main priority uses of forests in the Voronezh region, was carried out the distribution territory of forest areas for these types of forests and designed business income.

It was found that the activity will be profitable business organizations have chosen the path of integrated forest management - combination of recreation and harvesting.

\section{Discussion}

For business organizations impact assessment of forest users activity in the forestry sector is of particular importance due to the nature of forestry work, significant levels of risk combined with uncertainty in obtaining entrepreneurial income, determined by the level of availability of forest resources - accessible (revenues from forest management exceed the costs), the limit (income can be higher or lower costs) that are not available (costs exceed the income from forestry) (Denisov, 2013). For sparsely zone is characterized by two types of accessibility of forest resources are limits and inaccessible. In the case of available forest resources condition of entrepreneurial income is largely determined by forest fees and forestry encumbrance (Pukman \& Adamovskiy, 2013). Models of business organization in forestry sparsely region may be:

Firstly, the model is based on the support of business organizations operating in forest areas with maximum performance to-Feet forests representing the business interest. In this case, business structures important financial support in the form of a partition or full exemption from forest user's forest tax. Such a model is key-wills encourage implementation of tenants of the complex work of reforestation, forestry and others, including forest protection (Kondratuk, 2003). However, its implementation requires such factors as:

- Developed local wood;

- High prices for roundwood covering reforestation costs, to providing normal profitability of logging;

- Local budgets that can support business structures.

Second, in the absence of return woodlots best model institution and use of forests is the creation of state-owned enterprises - business organizations, in activities which combine complex forest management and forestry business. Given that the founder of such companies is the state of the net income is redistributed in the state budget, thus realized the financial component of the model.

We believe that in the run-up to the decision to start entrepreneurial figure-of forestry and to participate in the auction procedures to enter into a lease agreement for a business entity must assess the benefits from the exploitation of forests and the costs of forest management in accordance with the requirements of the forestry regulations.

In this case, such an assessment tool acts considered methodological approach to the analysis of the impact of business activities in the forestry owners.

\section{Conclusion}

Main point of reference in the reform of the Forest Code was the transfer governmental forestry work to private business (forest inventory work, forestry Started-you activities on biodiversity, hydro-forest-differentiation work 
recreational work, prevention of forest fires, protective afforestation etc.), Which marked the emergence of entrepreneurship in forestry.

Entrepreneurial interest connected with the organization of forest and getting of income in forestry is ambiguous and depends on the specific forestry works, significant levels of risk and the level of availability of forest resources. Mouth-established that in a sparsely wooded area of activity will be profitable business organizations have chosen the path of integrated forest management by combining recreation and logging.

Considered a methodical approach to the analysis of the impact of entrepreneurial activities in the forestry sector can be used in business planning by business entities that have an interest to create "their own business" in forestry. Lack of interest in business organizations in the implementation of forest management can be compensated for by the creation of state-owned enterprises and the implementation of the latest forestry production in the forestry sector sparsely wooded area.

In general, to promote the development of entrepreneurship in forestry need to develop standards to assess the conditions under which the creation and development of business is effective. Regulations may be the correction factor reflecting the cost of reforestation, differentiated by species composition and age structure of the stands, fire rating class, transport accessibility, the technology used to work in the forest.

\section{References}

Bao, Sh. (2013). The mechanism of development of small business in the forest. Socio-economic phenomena and processes, 12, 15-19.

Daminov, V. V., \& Pikalkina, M. G. (2011). Resourcing development programs of forest pro-industry. Bulletin of the Moscow State University of Forestry. Forestry Bulletin, 1(77), 155-158.

Denisova, G. (2013). Organizational-economic mechanism to ensure the development of entrepreneurship in forestry sparsely wooded area. Socio-economic phenomena and processes, 8(1), 15-18.

Drucker, P. F. (1992). Managing for results. Moscow: Progress.

Kondratuk, V. A. (2003). Efficiency forest complex: Problems, solutions. Forest pro-dustry, 1(1), 2-3.

Liski, J., Palosuo, T., Peltoniemi, M., \& Sievänen, R. (2005). Carbon and decomposition model Yasso for forest soils. Ecological Modelling, 189, 168-182. http://dx.doi.org/10.1016/j.ecolmodel.2005.03.005

McDermott, C. L., Humphreys, D., Wildburger, C., Wood, P., Marfo, E., Pacheco, P., \& Yasmi, Y. (2010). Mapping the core actors and issues defining forest governance. In J. Rayner, A. Buck, \& P. Katila (Eds.), Embracing complexity: Meeting the challenges of international forest governance. A global assessment report. Prepared by the Global Forest Expert Panel on the International Forest Regime. IUFRO World Series, 28, 19-36.

Milana, C. (1988). Constant-market-shares analysis and index number theory. European Journal of Political Economy, 4, 453-478. http://dx.doi.org/10.1016/0176-2680(88)90011-0

Morkovina S. S. (2014). Cluster approach to basis of forms of cooperation of the state and entrepreneurship in the forestry management of the sparsely wooded region. Life Science Journal, 11(10s), 423-427.

Morkovina, S. S., Zinoviev, I. S., Bao, Sh. (2014). The role and place of small business owners in the forestry-tion region sparsely Business. Bulletin of Institute of Business, 1(1), 21-23.

Popkova E. G., Shakhovskaya L. S., Volosatova, U. A., Ostrovskaya, V. N., \& Ponomareva, L. V. (2014). Economic efficiency management of the marketing activity of an ecology-oriented company. Life Sci J, $11(12 \mathrm{~s}), 180-184$.

Popkova, E. G., Morkovina, S. S., Patsyuk, E. V., Panyavina, E. A., \& Popov, E. V. (2013). Marketing strategy of overcoming of lag in development of economic systems. World Applied Sciences Journal, 26(5), 591-595

Popkova, E. G., Sharkova, A. V., Merzlova, M. P., Yakovlev, E. A., \& Nebesnaya, A. Y. (2013). Unsustainable models of regional clustering. World Applied Sciences Journal, 25(8), 1174-1180.

Postma, T. J. B. M., \& Liebl, F. (2005). How to improve scenario analysis as a strategic management tool? Technological Forecasting and Social Change, 72, 161-173. http://dx.doi.org/10.1016/j.techfore. 2003.11.005

Pukman, I. V., \& Adamovsky, A. N. (2013). Evolyutsiya approaches to multiple use forest management. Forest Engineering magazine, 2(1), 199-204.

Schelhaas, M. J., Hengeveld, G., Moriondo, M., Reinds, G. J., Kundzewicz, Z. W., ter Maat, H., \& Bindi, M. 
(2010). Assessing risk and adaptation options to fires and windstorms in European forestry. Mitigation and Adaptation Strategies, 15(7), 681-701. http://dx.doi.org/10.1007/s11027-010-9243-0

Tchaikovskaya, L. A. (2007). Forest income and charges for the use of forest resources. Audit and Financial Analysis, 5(1), 2-9.

Verkerk, P. J., Lindner, M., Zanchi, G., \& Zudin, S. (2011). Assessing impacts of intensified biomass removal on deadwood in European forests. Ecological Indicators, 11, 27-35. http://dx.doi.org/10.1016/j.ecolind. 2009.04.004

Zozulya, V. V. (2010). Taxation in the forestry sector: Problems and prospects / VV Zozulya. Herald Finance Academy, 1(55), 252-258.

\section{Copyrights}

Copyright for this article is retained by the author(s), with first publication rights granted to the journal.

This is an open-access article distributed under the terms and conditions of the Creative Commons Attribution license (http://creativecommons.org/licenses/by/3.0/). 